Governance and Politics of China 


\section{COMPARATIVE GOVERNMENT AND POLITICS}

Series Editor: Vincent Wright

\section{Published}

Rudy Andeweg and Galen A. Irwin

Governance and Politics of the Netherlands

Nigel Bowles

Government and Politics of the United States (2nd edition)

Paul Brooker

Non-Democratic Regimes: Theory, Government and Politics

Robert Elgie

Political Leadership in Liberal Democracies

Rod Hague and Martin Harrop

Comparative Government and Politics (5th edition)

Paul Heywood

The Government and Politics of Spain

B. Guy Peters

Comparative Politics: Theories and Methods

[Rights: World excluding North America]

Tony Saich

Governance and Politics of China

Anne Stevens

The Government and Politics of France (2nd edition)

Ramesh Thakur

The Government and Politics of India

Forthcoming

Judy Batt

Government and Politics in Eastern Europe

Robert Leonardi

Government and Politics in Italy

\section{Comparative Government and Politics}

Series Standing Order

ISBN 978-0-333-71693-9 hardcover

ISBN 978-0-333-69335-3 paperback

(outside North America only)

You can receive future titles in this series as they are published by placing a standing order. Please contact your bookseller or, in the case of difficulty, write to us at the address below with your name and address, the title of the series and an ISBN quoted above.

Customer Services Department, Macmillan Distribution Ltd

Houndmills, Basingstoke, Hampshire RG21 6XS, England 


\section{Governance and Politics of China}

Tony Saich

palgrave 


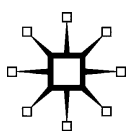

(C) Tony Saich 2001

All rights reserved. No reproduction, copy or transmission of this publication may be made without written permission.

No paragraph of this publication may be reproduced, copied or transmitted save with written permission or in accordance with the provisions of the Copyright, Designs and Patents Act 1988, or under the terms of any licence permitting limited copying issued by the Copyright Licensing Agency, 90 Tottenham Court Road, London W1T 4LP.

Any person who does any unauthorised act in relation to this publication may be liable to criminal prosecution and civil claims for damages.

The author has asserted his right to be identified as the author of this work in accordance with the Copyright, Designs and Patents Act 1988.

First published 2001 by

PALGRAVE

Houndmills, Basingstoke, Hampshire RG21 6XS and

175 Fifth Avenue, New York, N.Y. 10010

Companies and representatives throughout the world

PALGRAVE is the new global academic imprint of St. Martin's Press LLC Scholarly and Reference Division and Palgrave Publishers Ltd (formerly Macmillan Press Ltd).

ISBN 978-0-333-59486-5 hardback

$$
\text { ISBN 978-0-333-59487-2 ISBN 978-1-4039-0099-9 (eBook) }
$$$$
\text { DOI 10.1007/978-1-4039-0099-9 }
$$

This book is printed on paper suitable for recycling and made from fully managed and sustained forest sources.

A catalogue record for this book is available from the British Library.

Library of Congress Cataloging-in-Publication Data

Saich, Tony.

Governance and politics of China / Tony Saich.

$$
\text { p. cm. - (Comparative government and politics) }
$$

Includes bibliographical references and index.

ISBN 978-0-333-59486-5 (cloth) — ISBN 978-0-333-59487-2 (pbk.)

1. China-Politics and government-1949- 2. China-Economic policy-1949- I. Title. II. Series.

JQ1510.S26 2001

$951.05-d c 21$

$\begin{array}{rrrrrrrrrr}11 & 10 & 9 & 8 & 7 & 6 & 5 & 4 & 3 & 2 \\ 11 & 10 & 09 & 08 & 07 & 06 & 05 & 04 & 03 & 02\end{array}$


To Yinyin, Alex and Amanda 


\section{Contents}

List of Maps, Boxes, Figures and Tables $\quad \mathrm{x}$

Preface xii

Acknowledgements xvii

Romanization and Chinese Measures xviii

List of Abbreviations $\quad$ xix

1 Introduction 1

$\begin{array}{ll}\text { A land of diversity } & 2\end{array}$

$\begin{array}{ll}\text { The impact of CCP policy } & 11\end{array}$

2 China's Changing Road to Development: Political History, 1949-78 22

Parameters of policy debate 23

Economic recovery and the adoption of the Soviet model, 1949-55 27

The origins of a Chinese path to socialism, 1955-62 34

The radicalization of politics and the resurrection of

3 China Under Reform, 1978-2000 52

The Third Plenum and the initial reform agenda, 1978-84 52

Economic troubles and political instability, 1985-91 59

Return to economic reform, boom and moderation, 1992-97 69

$\begin{array}{ll}\text { Managing reform without Deng, 1997-2000 } & 73\end{array}$

$\begin{array}{ll}\text { Towards the Sixteenth Party Congress } & 78\end{array}$

4 The Chinese Communist Party 80

$\begin{array}{ll}\text { Party organization and membership } & 80\end{array}$

The role of the CCP in the political system 97

5 The Central Governing Apparatus $\quad 107$

$\begin{array}{ll}\text { Central government } & 110\end{array}$

$\begin{array}{ll}\text { The legal system, coercive control and rights } & 123\end{array}$

$\begin{array}{ll}\text { The military and the political system } & 131\end{array}$

6 Governance Beyond the Centre 141

$\begin{array}{ll}\text { The organization of local government } & 141\end{array}$

$\begin{array}{ll}\text { The province as a unit of analysis } & 143\end{array}$ 
Regional inequality 149

Relations between the centre and the localities: the fiscal picture 152

The consequences for local governance 155

7 Political Participation and Protest $\quad 164$

Mao Zedong and participation in theory and practice 164

Modernization and participation since Mao 166

Impact on the sanctioned organizational structure $\begin{array}{ll}\text { of representation } & 168\end{array}$

Participation at the grassroots and the role of elections 175

$\begin{array}{ll}\text { Non-sanctioned participation } & 184\end{array}$

8 The Chinese State and Society 194

The Maoist period: an autonomous state and a state-dominated society 194

State-society relations under reforms: a negotiated state 203

Of civil society, corporatism, predation and negotiation 205

9 Economic Policy $\quad 212$

Policy-making and implementation $\quad 212$

Economic policy 215

Gradualism or 'shock therapy' as a transitional strategy 216

General policy for economic reform $\quad 219$

Agricultural policy $\quad 222$

$\begin{array}{ll}\text { Industrial policy } & 229\end{array}$

$\begin{array}{ll}\text { Financial sector reform } & 237\end{array}$

10 Social Policy $\quad 241$

Social policy and the transition in China 241

Family planning: problems of policy coordination and policy $\begin{array}{ll}\text { evasion } & 246\end{array}$

Reform in the SOEs: cutting the Gordian knot 248

Providing adequate healthcare in urban China 254

Healthcare in rural China $\quad 257$

$\begin{array}{ll}\text { Poverty alleviation } & 261\end{array}$

Migration $\quad 266$

Improving rural social policy $\quad 269$

11 Foreign Policy 2

China and globalization $\quad 272$

China and the great power(s) 276

China and the region 284

China's foreign economic relations 286 
Contents ix

12 Challenges in the Twenty-First Century 294

The environmental challenge $\quad 294$

The internal challenge: corruption 299

The external challenge: the information revolution 306

The final challenge: political reform 310

$\begin{array}{ll}\text { Further Reading } & 315\end{array}$

$\begin{array}{ll}\text { Bibliography } & 320\end{array}$

$\begin{array}{ll}\text { Index } & 342\end{array}$ 


\section{List of Maps, Boxes, Figures and Tables}

Map

The People's Republic of China

$\mathrm{xxi}$

\section{Boxes}

1.1 Decisions taken on high can reach the farthest corners 6

$\begin{array}{ll}1.2 & \text { The party, religion and worship } \\ 1.3\end{array}$

$\begin{array}{ll}1.3 & \text { Dealing with HIV/AIDS in Yunnan } \\ & 18\end{array}$

2.1 Key dates of the communist revolution 23

2.2 Key political dates, 1949-78 24

$\begin{array}{ll}2.3 & \text { Revolutionary base areas } \\ 2.4 & 28\end{array}$

2.4 Stages of collectivization in the Chinese countryside 31

2.5 Key features of the Soviet model of development 32

2.6 Mao and the 'mass line' 41

2.7 Changing views of the cultural revolution 43

3.1 Key political dates, 1978-2000 53

3.2 Wei Jingsheng on the need for democracy 57

3.3 Perspectives on Tiananmen, $1989 \quad 66$

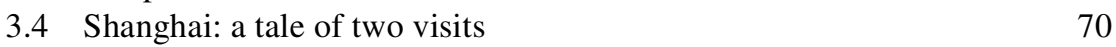

4.1 Neo-authoritarianism and neo-conservatism 82

4.2 Criticism CCP-style: Chen Boda's denunciation of Wang Shiwei 85

4.3 Party duty and personal choice 96

$\begin{array}{ll}5.1 \text { The problem of implementing court decisions } & 124\end{array}$

6.1 Misguided development in rural China 159

6.2 Restructuring local government: Qindu district 162

$\begin{array}{lll}7.1 & \text { Providing legal aid to rural women } & 173\end{array}$

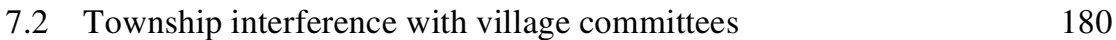

$\begin{array}{lll}7.3 & \text { Comrade Zhou fights corruption } & 188\end{array}$

$\begin{array}{lll}10.1 & \text { Designing a new pension system } & 250\end{array}$

10.2 New experimentation with cooperative medical provision 262

$\begin{array}{lll}10.3 & \text { Microfinance and women } & 266\end{array}$

12.1 Politics and corruption: the case of Xiamen 305

12.2 Governing in the age of information pluralism 307 


\section{Figures}

4.1 Organization of the Chinese Communist Party

4.2 Central organization of the CCP (simplified)

4.3 Party membership

5.1 Central organization of the Chinese government as of March $1998 \quad 113$

6.1 Levels of government under the State Council

\section{Table}

5.1 Restructuring of the State Council 


\section{Preface}

When the Soviet Union collapsed in 1991 many thought that it would not be long before the People's Republic of China followed. The Chinese Communist Party (CCP) had just survived the massive student-led demonstrations of 1989 that protested against official corruption and authoritarian political rule. These demonstrations by millions of urban Chinese exposed deep divisions within the senior leadership about the way forward and considerable disillusionment and distrust among society. The regime was only saved by the intervention of the People's Liberation Army (PLA) and it faced a major task to restore its tarnished image and authority, an authority that was weakened further by the subsequent economic recession. By 1992, senior leader Deng Xiaoping saw that any attempt to return to a more traditional, centrally-planned economy was doomed to failure and would undermine the party's remaining legitimacy. He recognized that the only way forward was for the CCP to deliver economic benefits to China's citizens and he set in train an economic free-for-all that ignited growth rates of 12 to 14 per cent and encouraged huge numbers of citizens and party, state and military officials to get involved in business. This clearly saved the regime but it also set off the highest inflation levels since the early years of the People's Republic of China (PRC), gave a boost to the rising corruption, and further loosened party control over state and society. As Jiang Zemin consolidated his power as party general secretary and Zhu Rongji took greater control over economic issues, they have wrestled to address these negative legacies by setting economic growth on a firmer footing while strengthening the authoritarian power structure.

At the same time, the leadership is grappling with the deeper legacies of its Soviet inheritance while trying to ready the nation for the shock of World Trade Organization (WTO) entry. It is no easy task and the challenges are complex for policy-makers. At the same time, they must provide policy responses and priorities for its industry and financial sector to compete internationally; transform its state-owned sector without encountering major social unrest; provide a new framework for urban social welfare and rebuild the rural system; legislate for a growing private economy; while dealing with de-industrialization in the cities they must accommodate industrialization of the countryside; and find employment for some 200 million surplus labourers in the countryside. Any one of these policy challenges could overwhelm a government's capacity, yet the CCP leaders must deal with all of them at the same time.

To do justice to this complexity in an introductory text is no easy matter. In the chapters below I have tried to present some of the complexities of dealing with the most populous country in the world. The danger is that almost anything one writes seems too simple but too many qualifications tend to confuse as much as 
clarify. It is a difficult line to tread. I hope that the book will be of interest not only to those beginning to thread their way through the maze of Chinese politics, but also to those who already know the basics as well as to students of comparative politics, transitional regimes, communist and post-communist politics, and the politics of development.

There are a number of specific problems with writing an introduction to Chinese politics. First, few have knowledge of the country before starting a university or other programme. China barely figures as a subject on the syllabus at secondary school. In addition, the general assumption that the institutions, theories and practices developed within Europe and the United States are the norm of politics means that the study of countries such as China are often pushed to the periphery of the syllabus.

Second, China is changing so fast that it is difficult to keep abreast of developments. It sets a challenge to highlight what is significant and enduring and to ignore what is irrelevant and ephemeral. China is a maze of intricacies, complexities and contradictions. In 2002 and 2003 the Sixteenth Party Congress and the Tenth National People's Congress (NPC) will meet. These meetings will herald a major leadership turnover and possibly new policy initiatives. Updates to this book in light of these meetings and other developments will be posted on the Palgrave website at http://www.palgrave.com.

Third, all political systems experience a disjuncture between political practice and rhetoric and between social reality and the desires of the political centre. This disjuncture is even greater in China. When Prime Minister Blair or President Bush makes a speech about their vision for their respective countries, no-one believes that this reflects entirely political and social reality. Such pronouncements provide a policy blueprint or political aspiration that is contested within the bureaucracy and by the local political authorities and society. Such visions represent an ideal type of the kind of society that the leaders would like to see. In the past some observers of the Chinese political scene took what leaders said to represent social reality and saw the political system as geared to implementing the pronouncements of the CCP's General Secretary. Perhaps the fact that China's ruling party still calls itself a communist party conjures up visions of a totalitarian political system that really does function with one heart and mind from top to bottom. Reality is quite different. Contrary to much press reporting and general perceptions, the political centre does not control the system throughout and there is significant deviation from central policy across bureaucracies and at the local level. In some senses, real politics in China is local politics. It is at the local level that problems have to be solved concerning economic policy and social equity. Policy implementation can vary enormously even within one province in accordance with the local distribution of power. This pluralism of policy outcome has led to different analyses of the Chinese state as being essentially predatory, corporatist, clientelist, or bureaucratic authoritarian. Making sense of this seemingly contradictory country is what makes the study of its politics and society so endlessly fascinating. 
This complexity is one of the main themes that runs through the book together with the notion that history and institutions matter. Reform did not begin with a blank slate in 1978 and even the best macro-economists have to deal with the fact that policy implementation is predicated on responses drawn from historical and cultural repertoires and mediated through political institutions that have been inherited from the Maoist years. The focus is on the politics and governance of China during this process of transition. The use of the term governance moves us beyond the functioning of government institutions and administrative departments to the broader issues of how individual citizens, groups and communities relate to the state. It includes processes and institutions, both formal and informal, which guide and restrain the policy challenges. Included are issues of accountability and transparency and the potential role of actors within civil society and the international community.

Three main themes emerge from the chapters below. First, the economic reform programme has been more consistently successful than many outside observers have predicted over the years, but it is now facing more significant challenges. The CCP has shown a remarkable capacity to adapt to the rapidly changing environment, and its performance has looked particularly impressive when compared to developments in post-Soviet Russia. However, the question now arises as to whether the limits of the current development strategy have been reached. Many of the problems now confronting China's leaders are those of delayed reform. Much of the initial success and popular support stemmed from the fact that there were relatively few losers and those who did lose out were politically marginalized. It is now apparent that as reform moves to the next stage and China integrates further into the world economy, there will be significant losers, including those workers and institutions that have formed the core of the CCP socialist system. The easy reforms have been completed and China has benefited enormously from a process of catching up with its East Asian neighbours. As one eminent Peking University professor said to me in the summer of 1999, 'reform' is no longer a popular word.

Time is no longer on the side of China's leaders, and with WTO entry looming the pace of change will accelerate. Muddling through might no longer be sufficient. At the end of the 1990s, deflation was a new problem and it was clear that the massive state-led investment programme has not stimulated the economy as expected and in any event cannot be a long-term solution. Future reform must get to grips with the problems of the financial sector to provide a sound environment for state-owned enterprise (SOE) restructuring, further investment and optimal use of savings. It must set as a priority expansion of the service sector that could provide a major source of future employment. However, this can only take place with a significant shift of investment resources to education. Without this, China will suffer from a continual shortage of skilled labour that will leave much of the country on the lower rungs of the production chain and it will not be able to follow the development strategies of Japan, South Korea and Taiwan. While most analysts focus on the question of state 
enterprise reform, this is a temporary problem and a political problem for the CCP given its traditional power base and privileging of an urban proletarian elite over other workers and farmers. The real challenge for the CCP remains as always in the countryside, and further reform of marketing and distribution needs to be pursued.

Second, China, like many transitional economies, has not been able to deal well with the social transition and the development of social policy has lagged badly behind economic development. In major part, this derives from the CCP's bias towards what it sees as productive forces and the health and education level of its population are not factored in sufficiently. Yet failure to tackle social policy effectively could also lead to undermining the progress made with economic reforms. For example, the demographics of China while currently favourable will begin to turn over the next 10 to 15 years. Unless China's leaders are able to get to grips with pension and other welfare reforms the economic advancement for many in this generation could be undone in the next by an unaffordable welfare burden.

China's leaders must also deal with the distribution of the benefits of the reforms. The current development strategy is highly inegalitarian and favours the coast over the inland areas, the urban over the rural, and male over female. The inability to develop the hinterland will act as a brake on economic growth as it will limit the size of the domestic market. It will also provide the potential for social conflict as the politics of resentment may arise. The urban bias of current policy needs to be changed and the structural impediments that block rural dwellers from benefiting fully from the reforms need to be removed. While women have enjoyed the general benefits of reform, more freedom of choice and rising prosperity, they have been disfavoured by comparison with men. They have been encouraged to retire early, are the first to be laid off from state-owned enterprises, bear the brunt of the family-planning programme, and shoulder a disproportionate amount of the rural labour. It is not surprising that women have no effective representation in the political system.

The third theme is that while there has been substantial adaptation of institutions, there has been insufficient genuine political reform. New institutions have been set up to manage the new economy and a legal system has been revived and extended to preside over it. Social organizations with varying degrees of autonomy have been established to meet people's material and leisure needs and, to a much lesser extent, their spiritual ones. However, with the exception of the village election programme, little has been done to make the system more accountable. The CCP still rules as an autocratic elite often out of touch with the consequences of its own economic policies. As good Marxists they should recognize that substantive change in the economic base must impact on the political superstructure. The truth is that Marx is irrelevant to their visions of the political future and those who may read more liberal tracts on the need for checks, balances and accountability keep quiet for fear of being branded a 'bourgeois liberal'. By default, theories of authoritarianism hold sway. At the local level, at its worst this 


\section{xvi Preface}

system can lead to rule by corrupt, despotic cabals who see the local population merely as a source of revenue. It is hard to see such a system providing the kind of stability that will produce long-term economic growth.

TONY SAICH

Update material for this title is available on the publisher's www site at http://www.palgrave.com/politics/saich/ 


\section{Acknowledgements}

First and foremost I should thank Steven Kennedy, my publisher at Palgrave. His persistence and good humour overcame my reservations about writing an introduction to Chinese politics. He was always helpful with creative advice and suggestions. He must have the patience to test a saint.

I am grateful to the students and staff of the Sinologisch Instituut, Leiden University, the Netherlands who provided a good environment for teaching and research. I would particularly like to thank my new academic home, the Kennedy School of Government, Harvard University, and the students in my 1999-2000 course 'The Political Economy of Transitions: Cases from China' where I tried out many of the ideas in this book. My understanding of contemporary China has been shaped by a number of teachers and friends, of whom David S.G. Goodman, Stuart R. Schram, and the late Gordon White deserve special mention. I trust that the references in the text do justice to the influence of the work of other colleagues. I would like to thank two anonymous referees for their comments. I did not agree with all they wrote but they saved me from making a number of mistakes and caused me to amend some judgements.

My formative experience of China was spent in Beijing and Nanjing at the end of the Cultural Revolution (1976-77). This experience opened my eyes to the complexity of Chinese reality and to take nothing at face value. Many of the ideas expressed in the book were shaped by this early experience and by my five years as Representative of the Ford Foundation in China (1994-99). I learned an enormous amount from our Chinese grantees and staff at the Beijing Office. I enjoyed wrestling policy issues with Mary Ann Burris, Phyllis Chang, James Harkness, Joan Kaufman, Stephen McGurk and Nick Menzies. In addition, Pieter Bottelier and Arthur Holcombe were always a source of advice. However, it is to my Chinese colleagues that I owe my greatest debt.

Nima Taylor helped enormously with the final editing of the text and the indexing and made a number of substantive suggestions. Nancy Hearst did a terrific job with the bibliography and picked up a number of errors that saved me from embarrassing myself even further. I would like to thank Nancy for all her help to the family and myself over the last 15 years or so.

Last I would like to thank Yinyin, Alex and Amanda to whom this book is dedicated.

TONY SAICH 


\section{Romanization and Chinese Measures}

The system of romanization for Chinese characters used in this book is the Pinyin system, as used by the PRC and scholars in the West. It may be adopted by Taiwan that has traditionally used the Wade-Giles system. Students will come across this system not only in publications from Taiwan but also in most of the works written before 1979. Also, there are numerous names with familiar spellings in English that belong to neither of these two systems. Two names have been used in their more familiar spelling - Chiang Kai-shek and Sun Yat-sen.

\section{Chinese Measures}

jin Weight measure equal to 0.5 of a kilogram.

ти Measure for land equal to one-sixth of an acre. Often spelt mou.

yuan Chinese currency unit. The value varies but in the year 2000 there were 8.3 yuan to the US dollar and 11.7 to the pound sterling. 


\section{List of Abbreviations}

\begin{tabular}{|c|c|}
\hline $\mathrm{ABC}$ & Agricultural Bank of China \\
\hline ACFTU & All-China Federation of Trade Unions \\
\hline AFP & Agence France Presse \\
\hline APEC & Asia-Pacific Economic Cooperation Forum \\
\hline ARF & ASEAN Regional Forum \\
\hline ASEAN & Association of Southeast Asian Nations \\
\hline $\mathrm{CC}$ & Central Committee \\
\hline $\mathrm{CCP}$ & Chinese Communist Party \\
\hline CEC & Central Executive Committee \\
\hline CNN & Cable News Network \\
\hline CMAC & Central Military Affairs Commission \\
\hline CPPCC & Chinese People's Political Consultative Conference \\
\hline CPSU & Communist Party of the Soviet Union \\
\hline EBF & Extra budgetary funds \\
\hline$F B I S-C H I$ & Foreign Broadcast Information Service - China \\
\hline FDI & Foreign direct investment \\
\hline FEER & Far Eastern Economic Review \\
\hline GDP & Gross domestic product \\
\hline GLF & Great Leap Forward \\
\hline GMD & Guomindang (Kuomintang, Nationalist Party) \\
\hline GNP & Gross national product \\
\hline GONGO & Government-Organized Non-Governmental Organization \\
\hline Jin-Cha-Ji & Shanxi-Chahar-Hebei \\
\hline Jin-Ji-Yu-Lu & Shanxi-Hebei-Shandong-Henan \\
\hline NATO & North Atlantic Treaty Organization \\
\hline NGO & Non-governmental organization \\
\hline NPC & National People's Congress \\
\hline PLA & People's Liberation Army \\
\hline Politburo & Political Bureau \\
\hline PRC & People's Republic of China \\
\hline SAR & Special Administrative Region \\
\hline$S C M P$ & South China Morning Post \\
\hline SFPC & State Family Planning Commission \\
\hline Shaan-Gan-Ning & Shaanxi-Gansu-Ningxia \\
\hline SOE & State-owned enterprise \\
\hline$S W B: F E$ & Summary of World Broadcasts: The Far East \\
\hline TVE & Township and village enterprises \\
\hline
\end{tabular}


$\mathrm{xx}$ List of Abbreviations

$\begin{array}{ll}\text { UN } & \text { United Nations } \\ \text { UNDP } & \text { United Nations Development Programme } \\ \text { US/USA } & \text { United States/United States of America } \\ \text { VAT } & \text { Value added tax } \\ \text { WHO } & \text { World Health Organization } \\ \text { WTO } & \text { World Trade Organization }\end{array}$




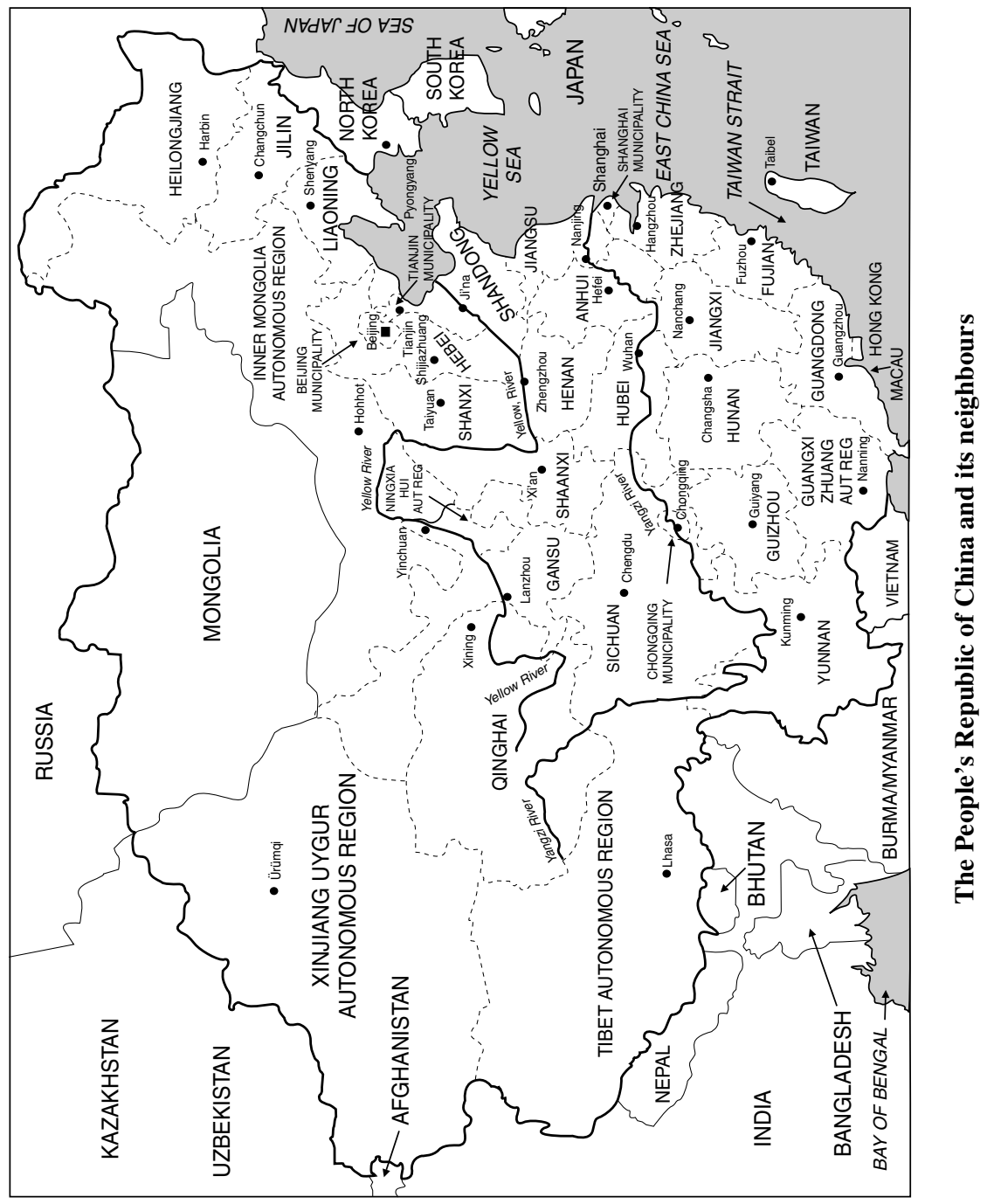

